\title{
Type I Collagen Is a Genetic Modifier of Matrix Metalloproteinase 2 in Murine Skeletal Development
}

\author{
Mikala Egeblad ${ }^{1},{ }^{*}$, H.-C. Jennifer Shen ${ }^{2, \dagger}$, Danielle J. Behonick ${ }^{1}$, Lisa Wilmes ${ }^{3}$, Alexandra \\ Eichten $^{2}$, Lidiya V. Korets ${ }^{2}$, Farrah Kheradmand ${ }^{4}$, Zena Werb ${ }^{1}$, and Lisa M. Coussens ${ }^{2}$ \\ 1 Department of Anatomy, University of California, San Francisco, San Francisco, California \\ 2The Cancer Research Institute, Department of Pathology and Comprehensive Cancer Center, University of \\ California, San Francisco, San Francisco, California \\ 3Department of Radiology, University of California, San Francisco, San Francisco, California \\ 4Division of Pulmonary and Critical Care, Baylor College of Medicine, Houston, Texas
}

\begin{abstract}
Recessive inactivating mutations in human matrix metalloproteinase 2 (MMP2, gelatinase A) are associated with syndromes that include abnormal facial appearance, short stature, and severe bone loss. Mmp $2^{-/-}$mice have only mild aspects of these abnormalities, suggesting that MMP2 function is redundant during skeletal development in the mouse. Here, we report that $M m p 2^{-/-}$mice with additional mutations that render type I collagen resistant to collagenase-mediated cleavage to $\mathrm{TC}^{\mathrm{A}}$ and $\mathrm{TC}^{\mathrm{B}}$ fragments $\left(\right.$ Collal $^{r / r}$ mice) have severe developmental defects resembling those observed in MMP2-null humans. Composite $\mathrm{Mmp}^{-/-} ; \mathrm{Collal}^{r / r}$ mice were born in expected Mendelian ratios but were half the size of wild-type, $\mathrm{Mmp}^{-{ }^{-/}}$, and Colla1 ${ }^{r / r}$ mice and failed to thrive. Furthermore, composite $\mathrm{Mmp}^{-/-} ;$Collal $^{r / r}$ animals had very abnormal craniofacial features with shorter snouts, bulging skulls, incompletely developed calvarial bones and unclosed cranial sutures. In addition, trabecular bone mass was reduced concomitant with increased numbers of bone-resorbing osteoclasts and osteopenia. In vitro, MMP2 had a unique ability among the collagenolytic MMPs to degrade mutant collagen, offering a possible explanation for the genetic interaction between Mmp2 and Collal $^{r}$. Thus, because mutations in the type I collagen gene alter the phenotype of mice with null mutations in $M m p 2$, we conclude that type I collagen is an important modifier gene for Mmp2.
\end{abstract}

\section{Keywords}

matrix metalloproteinase; type I collagen; osteopenia

\section{INTRODUCTION}

Remodeling of the extracellular matrix (ECM) by matrix metalloproteinases (MMPs) is critical for development of the skeleton, and mice deficient for Mmp9, Mmp13, and Mmp14 (Mt1mmp) have skeletal defects (Vu et al., 1998; Holmbeck et al., 1999; Zhou et al., 2000; Stickens et al., 2004). Inactivating mutations in human $M M P 2$ are the cause of rare but severe skeletal defect syndromes in patients born from consanguineous marriages (Martignetti et al., 2001;

\footnotetext{
*Correspondence to: Mikala Egeblad, Ph.D., Department of Anatomy, University of California, San Francisco, 513 Parnassus Avenue, Box 0452, San Francisco, CA 94143-0452. E-mail: mikala.egeblad@ucsf.edu

${ }^{\dagger}$ Dr. Shen's present address is National Cancer Institute, Center for Cancer Research, Advanced Technology Center, Rm110, 8717

Grovemont Circle, Bethesda, MD 20892-4605.
} 
Zankl et al., 2005; Rouzier et al., 2006). The clinical findings in these $M M P 2$-null patients include hyperextension of metacarpophalangeal joints, flexion contractures of large joints, dysmorphic faces, significant growth restrictions and, surprisingly, loss of bone mass with osteolysis (Al Aqeel et al., 2000; Al-Mayouf et al., 2000; Zankl et al., 2005; Rouzier et al., 2006). In contrast to $M M P 2$-null humans, $M m p 2^{-/-}$mice have mild skeletal defects and no focal osteolysis (Inoue et al., 2006).

Genetic modifiers are genes that interact with a phenotype-associated gene and alter the observed phenotype, for example the severity of the phenotype (Nadeau, 2001). Genetic modifier studies in mice can be powerful tools to identify genetic interactions with relevance for human disease. A recent example comes from cystic fibrosis, one of the most common human autosomal recessive diseases. Mutations in cystic fibrosis transmembrane conductance regulator $(C F T R)$, which encodes a membrane-bound chloride ion channel, cause impaired fluid and salt secretion resulting in mucus accumulation in various tissues. The clinical presentation of cystic fibrosis can vary with age-of-onset and disease severity and this variability has been ascribed both to differences in the specific mutations in the CFTR gene and to genetic modifiers (Nadeau, 2001). Mice deficient for the $C f t r$ gene $\left(C f t r^{-/}\right.$mice) die soon after birth on most genetic backgrounds, but live for many months on others. These observations indicate the existence of a modifier gene that modulates the severity of the phenotype of $C \mathrm{ftr}^{-/-}$mice. Through the intercrossing of mouse strains with different phenotypes and subsequent linkage analysis, a single locus with a semidominant effect on viability was identified (Rozmahel et al., 1996). The identification of the modifier locus in the mouse led to identification of the corresponding human locus, which turned out to be a genetic modifier of the human disease cystic fibrosis (Zielenski et al., 1999).

In the case of MMP2, the difference between the phenotype of $M m p 2^{--}$mice and $M M P 2$-null humans has been attributed to redundancy of Mmp2 gene function in the mouse (Martignetti et al., 2001). Because $\mathrm{Mmpl}^{4^{-/-}}$mice have severe skeletal defects with craniofacial abnormalities, growth restrictions, and osteopenia (Holmbeck et al., 1999; Zhou et al., 2000), it has been suggested that MMP14 in the mouse serves a function similar to MMP2 in human skeletal development (Martignetti et al., 2001). However, of the MMP2-null patients with osteolytic syndromes, all but one have been of Arabic descent and all have been born from consanguineous marriages. Thus, it is possible that there are genetic modifiers of $M M P 2$, which have cosegregated with the $M M P 2$ mutations in the affected individuals, and that such genetic modifiers are responsible for the reported different phenotypes of $M M P 2$-null humans and $\mathrm{Mmp}^{-{ }^{--}}$mice. We had noticed that a low percentage ( $\left.10 \%\right)$ of $\mathrm{Mmp}^{-{ }^{-/}}$mice from an inbred line on the C57BL/6 background were severely runted, had abnormally shaped faces, a wide gait, failed to thrive, and rarely lived beyond 4 weeks of age. The runted mice were always $\mathrm{Mmp}^{-\mathrm{I}^{-}}$, never wild-type or $\mathrm{Mmp}^{\mathrm{2}^{+-}}$. The low penetrance of the runted phenotype of $\mathrm{Mmp}^{-/-}$mice indicated existence of a recessive genetic modifier of $M m p 2$ in the mouse. Rather than identifying the putative modifier through linkage analysis, we took a candidate approach. The small stature and abnormal craniofacial features of the runted $M m p 2^{-/-}$mice resembled the appearance of $\mathrm{Mmpl}^{-/-}$mice (Holmbeck et al., 1999; Zhou et al., 2000), but because

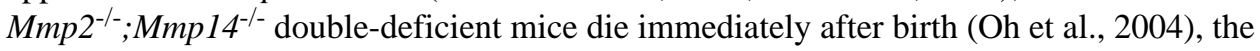
spontaneous mutation was unlikely to directly involve Mmp 14. MMP14 activates proMMP2 by cleaving off its prodomain (Strongin et al., 1995); thus, we speculated that a genetic modifier of Mmp2 could be another substrate of MMP14, namely type I collagen, which is also abundant in bones (Holmbeck et al., 1999).

Type I collagen is a heterotrimer molecule composed of two $\alpha 1$ (I) and one $\alpha 2$ (I) polypeptide chains encoded by two separate genes: Collal and Colla2 (Cutroneo, 2003). Type I collagen has both structural and signaling functions, the latter being mediated by integrins and discoidin domain receptors (Shrivastava et al., 1997; Heino, 2000). Type I collagen is cleaved into 
characteristic $\mathrm{TC}^{\mathrm{A}}$ and $\mathrm{TC}^{\mathrm{B}}$ fragments at approximately one quarter and three quarters of the length of the native molecule by collagenolytic MMPs, including MMP1, MMP2, MMP8, MMP13, and MMP14 (Ohuchi et al., 1997). These cleavage fragments are present in bone (Holmbeck et al., 1999; Stickens et al., 2004) and can initiate signaling that affects cell migration and survival (Montgomery et al., 1994; Petitclerc et al., 1999; Stringa et al., 2000; Fera et al., 2004).

Type I collagen is abundant in the skeleton where it contributes to load-bearing capacity by assembling into ordered fibrils. Naturally occurring mutations in type I collagen genes render type I collagen molecules more fragile and lead to osteogenesis imperfecta, characterized by profound skeletal fragility (Barsh et al., 1982, 1985; Bonadio et al., 1985). Conversely, Collal $^{r / r}$ mice with homozygous, engineered mutations (r) in the Collal gene, which render type I collagen resistant to cleavage to $\mathrm{TC}^{\mathrm{A}}$ and $\mathrm{TC}^{\mathrm{B}}$ fragments by collagenolytic MMPs (including MMP2, MMP8, MMP13, and MMP14), continually deposit new bone, resulting in progressive thickening of the calvariae and increased trabecular bone density (Liu et al., 1995; Zhao et al., 2000; Chiusaroli et al., 2003). Mice deficient for MMP13 or MMP14, which both have high activity against type I collagen, also display abnormal skeletal development (Holmbeck et al., 1999; Zhou et al., 2000; Stickens et al., 2004).

Here, we test the hypothesis that type I collagen is a modifier of Mmp2 during skeletal development in the mouse. We report that mice that concomitantly are deficient for $M m p 2$ and carry the mutant Collal $^{r}$ gene show skeletal changes resembling those reported in the human skeletal syndromes associated with inactivating mutations in $M M P 2$.

\section{RESULTS}

\section{Mmp2 $^{--} ;$Col1a1 ${ }^{r / r}$ Mice Are Severely Growth Retarded}

Collal ${ }^{r / r}$ mice have mutations in the Collal gene that render type I collagen resistant to cleavage by collagenolytic MMPs (Liu et al., 1995). To determine whether type I collagen was a modifier of Mmp2, we intercrossed $M m p 2^{-/-}$mice with Collal ${ }^{r / r}$ mice. When the resulting $\mathrm{Mmp2}^{+/-} ; \mathrm{Collal}^{r /+}$ mice were further intercrossed, Mendelian ratios of the nine possible genotypes were observed during embryogenesis and immediately after birth (Table 1). However, at weaning, 21 days after birth, the distribution of the genotypes was significantly different from the expected values with fewer than expected $\mathrm{Mmp2}^{-/-} ; \mathrm{Collal}^{r /+}$ and $M m p 2^{-/-} ;$Colla $^{r / r}$ mice (Table $1, \chi^{2}=24.7 ; P=0.002$ ). Thus, whereas $M m p 2^{-/-}$and Colla1 $^{r / r}$ mice had normal survival, $\mathrm{Mmp}^{-{ }^{-/}}$mice with at least one Colla1 ${ }^{r}$ allele showed reduced postnatal survival.

The $\mathrm{Mmp}^{-{ }^{--}} ;$Colla $^{r / r}$ mice were only approximately half the size of wild-type, $M m p 2^{-/-}$or

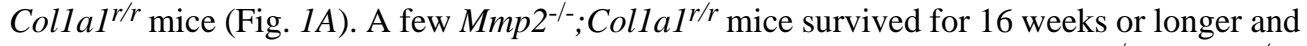
their body weight was recorded weekly. At birth, the body weight of the $\mathrm{Mmp}^{-/-} ; \mathrm{Collal}^{r / r}$ mice was comparable to wild-type, $\mathrm{Mmp}^{-{ }^{-/}}$, and Collal ${ }^{r / r}$ mice. However, the weight of the $\mathrm{Mmp}^{-{ }^{--}} ;$Collal $^{r / r}$ mice failed to increase from approximately the fourth week of age, coinciding with the growth spurt of the long bones, and remained significantly less than the weights of wild-type, $\mathrm{Mmp}^{-/-}$, or Collal ${ }^{r / r}$ mice for the duration of their lifetime (Fig. 1B). The runted phenotype showed $100 \%$ penetrance in $\mathrm{Mmp}^{-/-} ; \mathrm{Collal}^{r / r}$ mice and was also often found in $\mathrm{Mmp2}^{-/-} ;$Collal $^{r /+}$ mice, whereas $\mathrm{Mmp2}^{+/-} ;$Colla $^{r / r}$ animals were not runted (data not shown). None of the $\mathrm{Mmp}^{-{ }^{--}} ;$Colla ${ }^{r / r}$ mice were able to produce offspring. 


\section{$\mathrm{Mmp2}^{-/-} ; \mathrm{Col1a1}^{\mathrm{r} / \mathrm{r}}$ Mice Have Edematous Paws, Hyperextended Metacarpophalangeal Joints, and Reduced Mobility of Large Joints}

Humans with inactivating $M M P 2$ mutations have characteristic swelling of fingers and toes, hyperextension of metacarpophalangeal joints, and either hyperextension or flexion contracture of most other joints (Al Aqeel et al., 2000). While handling $\mathrm{Mmp2}^{-/-} ; \mathrm{Collal}^{r / r}$ mice, we noticed that their range of motion, particularly of the knee, hip, shoulder, and elbow joints, was markedly reduced ( 8 of 8 mice). Strikingly, paws of the $\mathrm{Mmp}^{-/-} ;$Colla $^{r / r}$ mice became visibly swollen, and the metacarpophalangeal joints hyperextended around the time of weaning (Fig. 1C). To establish if the increased size of their paws was due to edema, we determined the apparent diffusion coefficient (ADC) using diffusion weighted magnetic resonance imaging (MRI). The ADC is an indirect measure of water content with a higher value reflecting increased water mobility (Le Bihan et al., 1986), which can result from the expanded interstitial space characteristic of edema. The ADC was greater in hind paws of Mmp2 $^{-/-} ;$Collal ${ }^{r / r}$ mice $\left([1.30 \pm 0.05] \times 10^{-3} \mathrm{~mm}^{2} / \mathrm{sec}, \mathrm{n}=2\right)$ than in control mice $([0.98 \pm$ $0.03] \times 10^{-3} \mathrm{~mm}^{2} / \mathrm{sec}, \mathrm{n}=2$, one aged-matched wild-type and one $\mathrm{Mmp2}^{+/-} ;$Colla $^{r / r}$ littermate). These results indicate that the paws of the $\mathrm{Mmp}^{-/-} ; \mathrm{Colla}^{r / r}$ mice were edematous. Tissue involved in edema was most likely soft tissue because the T2-hyperintense regions with the highest ADC values were located at the periphery of the paws (data not shown).

\section{$\mathrm{Mmp2}^{-/-} ;$Col1a1 $^{\text {r/r }}$ Mice Display Abnormal Craniofacial Development With Impaired Calvarial Ossification and Lack of Calvarial Suture Closure}

Humans with recessive mutations in $M M P 2$ have flattened faces (Al Aqeel et al., 2000; AlMayouf et al., 2000; Zankl et al., 2005). The facial features were also changed in the $\mathrm{Mmp2}^{-/-} ;$Collal $^{r / r}$ mice, which had shortened snouts and bulging skulls (Fig. 2A,B). Facial changes of the $\mathrm{Mmp2}^{-/-}$; Colla ${ }^{r / r}$ mice were accompanied by incomplete intramembranous ossification of calvarial bones (Fig. 2C,D). Even in the single 5-month-old

$\mathrm{Mmp2}^{-/-}$; Collal ${ }^{r / r}$ mouse that we were able to study, calvarial bones had not completely ossified (data not shown). Instead of bone, a sclerotic membrane was present in adult animals. Mild delays were also evident in Mmp $2^{-/-}$and Collal ${ }^{r / r}$ mice, but the cranial sutures of the single mutants were closed completely by 8 weeks of age (Fig. 2C). The cranial bones that developed in $\mathrm{Mmp}^{-/-} ;$Colla $^{r / r}$ mice had a very abnormal histology with a thin and porous appearance (Fig. 2E). The bones from Coll al ${ }^{r / r}$ mice were slightly osteopetrotic as previously reported (Zhao et al., 2000).

\section{Long Bones of $\mathrm{Mmp2}^{--} ; \mathrm{Col1a}^{\mathrm{r} / \mathrm{r}}$ Mice Are Osteopenic}

In contrast to the severe defects in cranial development, long bones of $\mathrm{Mmp}^{-\mathrm{I}^{-}} ; \mathrm{Collal} \mathrm{I}^{r / \mathrm{r}}$ appeared largely normal, although smaller, when examined by whole skeletal preparation (Fig. $3 \mathrm{~A})$. Humans with $M M P 2$-null mutations suffer from osteolytic lesions in their long bones that can be so debilitating that they become wheel-chair-bound (Al-Mayouf et al., 2000).

Microcomputed tomography (micro-CT) analysis of $\mathrm{Mmp}^{-/-} ; \mathrm{Collal}^{r / r}$ mice showed reduced trabecular bone density in tibiae, indicating osteopenia (Fig. 3B; due to the reduced survival of the $\mathrm{Mmp2}^{-/-}$; Collal $^{r / r}$ mice, only one animal was analyzed at 16 weeks of age). The relative bone volume (BV/TV), which takes into account that $\mathrm{Mmp2}^{-1-} ; \mathrm{Collal}^{r / r}$ mice are significantly smaller than their controls, was much lower in tibiae from $\mathrm{Mmp}^{-{ }^{--}} ;$Colla $^{r / r}$ than from wildtype, $\mathrm{Mmp}^{-/-}$, or Colla ${ }^{r / r}$ agedmatched controls (Fig. 3C). Similarly, trabecular thickness (DT-Tb.Th) and cortical thickness at the diaphysis (DT-C.Th-Diaph) were lower in $\mathrm{Mmp}^{-{ }^{--}} ;$Colla $^{r / r}$ mice than in controls. Trabecular separation (TRI-Tb.Sp) was increased in $\mathrm{Mmp2}^{--}$;Colla ${ }^{r / r}$ mice compared with controls, indicating active bone resorption (Fig. 3C); however, the increase was skewed by the one 16-week-old $\mathrm{Mmp}^{-/-} ;$Collal $^{r / r}$ mouse.

Interestingly, this mouse had the lowest bone volume and highest trabecular separation of all the mice (Fig. 3C, red triangular symbols). Both type I collagen and MMP2 are expressed by 
osteoblasts in the trabecular bone (Dacquin et al., 2002;Stickens et al., 2004), and Safranin-O/ Fast Green staining demonstrated that there was less trabecular bone in tibiae of $\mathrm{Mmp}^{-/-} ;$Collal $^{r / r}$ than in control Mmp2 $2^{+/-} ;$Collal $^{r / r}$ littermates (Fig. 3D). In addition, the number of tartrate-resistant acid phosphatase (TRAP)-positive osteoclasts was increased in both trabecular and cortical bone in $\mathrm{Mmp}^{-/-} ;$Collal $^{r / r}$ mice compared with aged-matched controls (Fig. 3E).

\section{MMP2 Degrades Collagenase-Resistant Type I Collagen at Physiological Temperatures}

MMP2 is important for degradation of denatured, cleaved type I collagen, and, although it is often not considered a type I collagenase, it also has activity against native type I collagen (Tournier et al., 1994; Aimes and Quigley, 1995; Tam et al., 2004). The genetic interaction between Mmp2 and Collal ${ }^{r / r}$ indicated that type I collagen could be a direct substrate of MMP2. Therefore, we compared the ability of MMP2 to degrade normal and mutant collagen in vitro with two classic collagenolytic MMPs: MMP13 and MMP14. At $25^{\circ} \mathrm{C}, \mathrm{MMP} 13$ and MMP14 degraded wild-type collagen, resulting in generation of the classic $\mathrm{TC}^{\mathrm{A}}$ fragments, MMP2 had no activity against wild-type collagen, and none of the MMPs degraded the mutant collagen (Fig. 4A), as previously reported (Liu et al., 1995). However, at the physiological temperature of $37^{\circ} \mathrm{C}$, MMP2 degraded wild-type and, even more efficiently, mutant collagen, but degradation did not generate $\mathrm{TC}^{\mathrm{A}}$ fragments. In contrast, MMP13 and MMP14 still had reduced activity against mutant collagen at $37^{\circ} \mathrm{C}$ (Fig. 4B). Thus, the genetic interaction between Mmp2 and Collal ${ }^{r}$ could be caused by a requirement for MMP2 activity to degrade mutant type I collagen.

\section{DISCUSSION}

\section{Mmp2 $^{-/-} ;$Col1a1 $^{r / r}$ Mice Have Skeletal Defects Resembling Those of Humans With MMP2 Null Mutations}

Humans null for $M M P 2$ have severe osteolytic syndromes, whereas $M m p 2^{-/-}$mice have only mild skeletal defects (Itoh et al., 1997; Al Aqeel et al., 2000; Al-Mayouf et al., 2000; Martignetti et al., 2001; Zankl et al., 2005; Inoue et al., 2006; Rouzier et al., 2006). The spontaneous occurrence of a low penetrance, runted phenotype with abnormal craniofacial features in our $\mathrm{Mmp2}^{-/-}$mouse colony led us to hypothesize that there were genetic modifiers of Mmp2. Rather than identifying the specific genetic modification in our line, we took a candidate approach: proMMP2 is a substrate of MMP14, and we speculated that type I collagen, another classic MMP14 substrate with established function in bone development, could modify Mmp2. Indeed, severe skeletal developmental defects were observed when $\mathrm{Mmp}^{-{ }^{--}}$mice were intercrossed with Collal ${ }^{r / r}$ mice, which carry targeted mutations in the Collal gene rendering type I collagen resistant to classic collagenase cleavage. These $\mathrm{Mmp}^{-/-} ; \mathrm{Collal}^{r / r}$ mice had several striking similarities to humans with $M M P 2$-null mutations: in addition to decreased body size, these mice had osteopenic bones, craniofacial defects, failure to close calvarial sutures, decreased range of motion of joints, hyperextended metacarpophalangeal joints, and edematous paws (Table 2). Thus, we conclude that, in mice, type I collagen is a genetic modifier of MMP2, possibly because MMP2 can degrade mutant collagen (r). The Colla1 ${ }^{r}$ mutation is a dominant modifier on the $M m p 2^{-/-}$background, because the phenotype of $\mathrm{Mmp2}^{-\mathrm{I}^{-}} ; \mathrm{Collal}^{r /+}$ resembled the phenotype of $\mathrm{Mmp}^{-{ }^{--}} ;$Collal $^{r / r}$ mice. In contrast, the low penetrance of the spontaneously runted $\mathrm{Mmp}^{-{ }^{--}}$phenotype is suggestive of a recessive modifier. Thus, it is unlikely that the spontaneously runted phenotype is due to a mutation that renders type I collagen resistant to MMP-mediated cleavage. It, therefore, remains to be determined if the spontaneously runted $M m p 2^{-/-}$mice harbor other mutations that also affect collagen metabolism or if additional, collagen-independent, genetic modifiers of Mmp2 exist. 


\section{Reduced Extracellular Matrix Degradation Can Result in Reduced Bone Mass}

A priori, loss of a matrix-degrading enzyme, such as MMP2, would be expected to result in reduced bone remodeling and an osteopetrotic phenotype. Therefore, it was surprising that $M M P 2$-null mutations were associated with reduced bone mass and osteolysis in human genetic linkage studies (Martignetti et al., 2001). Our study now confirms the human findings: absence of MMP2 activity can result in osteopenia. MMP2 is a substrate of MMP14, and Mmp14-/mice are another example of an osteopenic phenotype that results from the absence of matrix degrading activity (Holmbeck et al., 1999). Additional similarities between $\mathrm{Mmpl}^{-/-}$and $\mathrm{Mmp}^{-1-} ;$ Collal $^{r / r}$ mice are the decreased body size, abnormal craniofacial features, and lack of calvarial suture closure. These similarities strongly suggest that proMMP2 and type I collagen are important substrates of MMP14 in bone development. However, MMP14 has other substrates, including proMMP13, which is important for endochondral ossification (Cowell et al., 1998; Stickens et al., 2004). Thus, a detailed comparison of endochondral

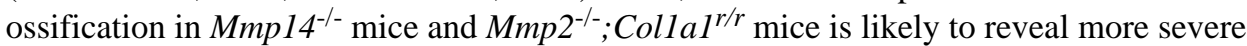
defects in Mmp $14^{-/-}$than in $\mathrm{Mmp2}^{-/-}$; Collal ${ }^{r / r}$ mice. Mmp $2^{-/-} ;$Colla $^{r / r}$ mice developed edema of the paws, probably localized to soft tissues. In $\mathrm{Mmpl}^{-/-}$mice, soft tissue changes, arthritis, and joint destruction have been reported (Holmbeck et al., 1999). Thus, it is possible that the edema in the $\mathrm{Mmp}^{-/-} ; \mathrm{Collal}^{r / r}$ paws is secondary to changes in the joints, although a partial analysis of joints did not reveal apparent destruction. As would be expected,

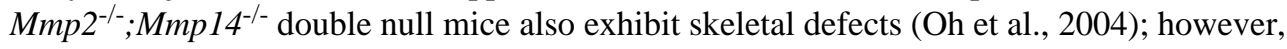
due to their perinatal lethality, these defects are not well characterized.

The reduced bone mass in the absence of matrix degradation may be partly explained by a reduced ability to degrade the embryonic cartilage matrix, which is required before osteoblasts can invade into the developing tissue and deposit bone matrix (Holmbeck et al., 1999). However, this finding would not explain the progressive bone loss observed in MMP2-null humans (Al Aqeel et al., 2000; Al-Mayouf et al., 2000; Rouzier et al., 2006). Because of the poor survival of the mice, we were limited to examining bone tissue from relatively young (7-8 weeks old) $\mathrm{Mmp}^{-{ }^{--}} ;$Coll $^{\mathrm{r}} \mathrm{r}^{\mathrm{r} / \mathrm{r}}$ mice and could not perform a proper analysis of whether the bone loss was progressive. Nevertheless, there was a strong trend for progressive bone loss by micro-CT analysis when comparing bones from 7- to 8-week-old mice with that of the one 16week-old mouse we could analyze. Thus, our data are consistent with the clinical findings that absence of MMP2 activity results in progressive bone loss, suggesting that the balance between bone deposition and bone resorption is skewed.

It may seem particularly surprising that combining Mmp2 null mutations with the Colla1 ${ }^{r}$ mutation results in such a strong osteopenic bone phenotype because Colla $1^{r / r}$ mice are osteopetrotic and in response to parathyroid hormone they have a severe impairment both in the generation of osteoclasts and in bone resorption (Zhao et al., 1999; Chiusaroli et al., 2003). Intriguingly, the porous calvarial phenotype we observed in the $\mathrm{Mmp}^{-1-} ; \mathrm{Collal}^{r / r}$ mice appeared as if increased bone resorption was taking place on the osteopetrotic background of the Colla1 ${ }^{r / r}$ mice. Osteoclast numbers are increased in the long bones of $\mathrm{Collal}^{r / r}$ mice even though activity is not (Chiusaroli et al., 2003). Thus, it appears that parathyroid hormone is not the right stimulus for induction of bone resorption in the Collal ${ }^{r / r}$ mice, whereas the absence of MMP2 is.

\section{Type I Collagen Metabolism in Bone Development}

Type I collagen regulates osteoblast and osteoclast activity in engineered mouse models (Zhao et al., 2000; Kalajzic et al., 2002), but the molecular mechanisms involved are not clear. $\mathrm{TC}^{\mathrm{A}}$ and $\mathrm{TC}^{\mathrm{B}}$ fragments of type I collagen are present in developing bone (Holmbeck et al., 1999; Stickens et al., 2004). These collagen fragments can ligate the $\alpha v \beta 3$ integrin (Montgomery et al., 1994), and both osteoblasts and osteoclasts express $\alpha v \beta 3$ integrins (Cheng 
et al., 2000; Zhao et al., 2005). Because of the Collalr mutation, the $\mathrm{TC}^{\mathrm{A}}$ and $\mathrm{TC}^{\mathrm{B}}$ fragments are not generated in the Collal ${ }^{r / r}$ mice, but the mutation could also affect the stability and conformation of the collagen triple helix. Changes in stability and conformation could affect both the unfolding of the triple helix that is necessary for collagenase cleavage (Zhao et al., 2000) and the ability of the collagen molecules to interact with other ECM components. Thus, we cannot conclude whether the absence of normal or presence of mutant fibrillar collagen is important for the observed developmental defects.

The Collal ${ }^{r}$ mutation affects the ability of all classic collagenolytic MMPs to generate $\mathrm{TC}^{\mathrm{A}}$ and $\mathrm{TC}^{\mathrm{B}}$ fragments. In vitro, MMP2 had much higher activity against mutant type I collagen than classic collagenolytic MMPs (MMP8, MMP13, and MMP14) and the strong phenotype of mice with the Collal ${ }^{r}$ mutation in the absence of MMP2 activity indicates that other collagenolytic MMPs are unlikely to compensate for MMP2 in vivo. Therefore, the phenotype observed in $\mathrm{Mmp}^{-/-} ;$Collal $^{r / r}$ mice is likely attributable not only to a loss of MMP2 activity against type I collagen, but to a near total loss of MMP-mediated degradation of type I collagen.

\section{MMP2 Has Activity Against Type I Collagen}

MMP2 is important for degradation of denatured, cleaved, type I collagen but also has direct activity against type I collagen (Tournier et al., 1994; Aimes and Quigley, 1995; Tam et al., 2004). Interestingly, MMP2 had higher activity against mutant type I collagen than normal type I collagen at physiological temperatures, whereas the opposite was true for the classic collagenolytic MMPs. MMP2 unfolds type I collagen by a mechanism distinct from the classic collagenases (Tam et al., 2004), and might, therefore, be more efficient at degrading mutant type I collagen with slight conformational changes. We also observed reduced survival of the $\mathrm{Mmp}^{-/-} ;$Colla1 $^{r /+}$ mice with one wild-type Collal allele, and these mice were also often runted with stiff joints and abnormal craniofacial features. These phenotypes were not observed in the $\mathrm{Mmp2}^{-/+}$; Collal ${ }^{r / r}$ mice with one remaining wild-type Mmp2 allele, suggesting that MMP2 activity is absolutely required for degradation of mutant type I collagen in vivo. In vitro, we demonstrated that MMP2 was able to degrade both wildtype and mutant type I collagen, and the genetic interaction between Mmp2 and Collal ${ }^{r}$ might, therefore, be due to direct biochemical interactions between the MMP2 enzyme and one of its substrates, type I collagen.

\section{Conclusions and Future Perspectives}

Inactivating mutations in Mmp2 have mild effects on skeletal development in the mouse (Inoue et al., 2006). Here, we show that concomitant mutations in both Mmp2 and Collal result in a severe runted and osteopenic phenotype that resembles the osteolytic syndromes found in humans with $M M P 2$ null mutations. Our results raise the interesting possibility that genetic modifiers of $M M P 2$ may also play a role in the human osteolytic syndromes. MMP2 was much more efficient at degrading mutant type I collagen than were the classic collagenases.

Therefore, minor mutations in type I collagen or in enzymes involved in its processing, which would go largely unnoticed on their own, could result in severe disease in the absence of MMP2 activity. Of interest, approximately $35 \%$ of the population carries a polymorphism of the COL1A1 gene that increases the ratio of the type I collagen $\alpha 1$ (I) chain to $\alpha 2$ (I) chain and is associated with a slightly decreased bone mass (Mann et al., 2001; Ralston et al., 2006). The strength of mouse genetics has allowed us to identify a genetic interaction between Mmp2 and type I collagen in skeletal development. Similarly, mouse genetics were instrumental in the identification of a genetic modifier of the CFTR gene (reviewed in Nadeau, 2001). The human syndromes (the Winchester, Torg, and nodulosis-arthropathy-osteolysis [NAO] syndromes) associated with MMP2-null mutations vary in severity and whether or not subcutaneous fibrillar nodules are present (Zankl et al., 2007). Such variation may be accounted for if genetic modifiers of $M M P 2$ also exist in humans. The results of our study indicate that type I collagen 
and enzymes involved in collagen metabolism are interesting candidate modifiers for these devastating human syndromes. In conclusion, using mouse genetics, we have confirmed the surprising results from the human genetic linkage studies: the lack of a matrix-degrading enzyme, MMP2, can result in increased bone degradation in the context of an abnormal matrix.

\section{EXPERIMENTAL PROCEDURES}

\section{Mice}

$\mathrm{Mmp}^{-/-}$mice (Itoh et al., 1997) and Collal ${ }^{r / r}$ mice (Liu et al., 1995) were bred into the FVB/ $\mathrm{n}$ background for four or more generations before generating $\mathrm{Mmp2}^{-/-} ; \mathrm{Collal}^{r / r}$ mice. Mice were genotyped by polymerase chain reaction for the wild-type $M m p 2$ allele (primers GelA2_sense $=5^{\prime}$-CAACGATGGAGGCACGAGTG-3' and GelA_antis=5' GCCGGGGAACTTGATCATGG-3'), for the $M m p 2$ null allele (primers GelAmut-1=5'GACCACCAAGCGAAACAT- $3^{\prime}$ and GelAmut-2=5'-CAAGAAGGCGATAGAAGG-3'), for the wild-type Collal allele (primers Col1a1wt-1=5'-TGGACAACGTGGTGTGGTC-3' and Colla1-wt-2=5'-TTGAACTCAGGAATTTACCTGC-3'), and for the mutated Collal ${ }^{r}$ allele (primers Col1a1mut-1= 5'-TGGACAACGTGGTGCCGCG-3' and Col1a1wt-2). Mice were housed in a specific-pathogen-free environment, under light-, temperature-, and humidity-controlled conditions with food and water available ad libitum. All mice were maintained and handled according to IACUC procedures.

\section{Embryonic and Neonatal Lethality}

$\mathrm{Mmp2}^{+/-} ; \mathrm{CollaI}^{r /+}$ mice were interbred to determine whether all genotypes were present in the expected Mendelian ratios. Embryos were collected, and yolk sac DNA was genotyped at embryonic day 9.5 or 14.5, and pups were collected, and tail DNA genotyped at birth (p1) or at weaning (p21).

\section{Weight Curves}

Wild-type, $\mathrm{Mmp2}^{-{ }^{--}}$, Colla1 ${ }^{r / r}$, and $\mathrm{Mmp}^{-{ }^{--}} ;$Collal $^{r / r}$ male and female mice were weighed weekly. At least three animals of each sex and genotype were followed until 16 weeks of age.

\section{Skull and Skeletal Preparations}

Whole skeleton and skull preparations were prepared by removing skin and internal organs, fixing overnight in 4\% paraformaldehyde (PFA), washing in increasing concentrations of ethanol, and staining overnight with Alcian blue (Sigma A3157-10G). Skeletons and skulls were then washed in ethanol, digested in $1 \%$ trypsin in $30 \%$ sodium borate until soft tissue became transparent, rinsed, stained in Alizarin red (Sigma A5533), incubated for 18-48 hr in $0.5 \% \mathrm{KOH} / 0.6 \% \mathrm{H}_{2} \mathrm{O}_{2}$, washed in increasing concentrations of glycerin, and stored in $100 \%$ glycerine.

\section{Quantification of Calvarial Bone Formation}

Skulls were photographed on a stereo microscope (Leica, MZFL111) with a digital camera (Nikon, DXM1200) using ACT-1 software (Nikon). The area that had not ossified was quantified using NIH Image J 1.34s software.

\section{Histological Staining}

Tissues were fixed in 4\% PFA and decalcified in 19\% ethylenediaminetetraacetic acid for 2 weeks before embedding in paraffin and sectioning at $5 \mu \mathrm{m}$. Deparaffinized and rehydrated sections were stained with hematoxylin and eosin using standard methods. For Safranin-O/ Fast Green staining, sections were stained in Weigert's Iron Hematoxylin (Sigma), 0.02\% aqueous Fast Green (Sigma), followed by a rinse in $1 \%$ acetic acid and $0.1 \%$ aqueous Safranin- 
O (Sigma). Sections were reacted for TRAP activity using a leukocyte acid phosphatase kit and counterstained with $0.02 \%$ aqueous Fast Green (Sigma).

MRI

MRI images were acquired on a 1.5T Signa whole body MRI scanner (General Electric Medical Systems). Anesthetized mice were imaged in pairs (an aged-matched wild-type or littermate $\mathrm{Mmp2}^{+/-} ;$Collal $^{r / r}$ mouse with an Mmp2 $2^{-/-} ;$Collal $^{r / r}$ mouse) using a wrist radiofrequency coil (Medical Advances, Milwaukee, WI) and a customized animal holder. Normal body temperature was maintained during imaging with a heating pad. Axial T2-weighted images were acquired using a two-dimensional multislice fast spin echo sequence (repetition time [TR] $=5.5 \mathrm{sec}$, echo time $[\mathrm{TE}]=85 \mathrm{msec}$ ) with an 8 -cm field of view (FOV), $256 \times 192$ matrix, and 3 -mm slice thickness to obtain cross-sectional images of the hind paws of the mice. Axial diffusion weighted images were acquired for the same slice locations using a single-shot fast spin echo $(\mathrm{TR}=9.5 \mathrm{sec} ; \mathrm{TE}=85 \mathrm{msec} ; \mathrm{FOV}=8 \mathrm{~cm}$, thickness $=3 \mathrm{~mm}, 128 \times 128$ matrix, and $b$ values of 0 and $600 \mathrm{~s} / \mathrm{mm}^{2}$ ). Water ADC maps demonstrating water mobility in the tissues were calculated as previously described (Partridge et al., 2001), and paw ADC values were determined using regions of interest delineated on T2-weighed images.

\section{Micro-CT}

Tibiae were collected at indicated ages and analyzed using a micro-CT system (mCT40, Scanco Medical, Bassersdorf, Switzerland). The trabeculae of the bones were scanned using a ConeBeam type scan into 240 slices with a voxel of $7 \times 7 \times 7 \mu \mathrm{m}$. Three-dimensional structural parameters were measured directly as described (Jiang et al., 2003).

\section{Preparation of Collagens and Digestion With Collagenases}

Collagens were extracted from wild-type or Colla ${ }^{r / r}$ mouse tails, digested with APMAactivated recombinant MMPs (Calbiochem, CA) for $1 \mathrm{hr}$ at the indicated temperatures, and analyzed by sodium dodecyl sulfate-polyacrylamide gel electrophoresis as described previously (Liu et al., 1995). Each sample contained $1 \mu \mathrm{g}$ type I collagen.

\section{Statistical Analysis}

Statistical analysis was performed using GraphPad Prism 4 and Microsoft Office Excel 2003. The distributions of genotypes after inter-breeding $\mathrm{Mmp}^{-/+} ; \mathrm{Collal}^{r /+}$ mice were compared with the expected Mendelian distributions with $\chi^{2}$ test ( 8 degrees of freedom). Growth curves of mice (repeated measurements) were analyzed by two-way analysis of variance repeated measurements test for time points with at least three mice per genotype. For males, curves were significantly influenced by genotype, $P<0.0001(\mathrm{~F}=173.39)$ and Bonferroni posttests showed that $\mathrm{Mmp2}^{-{ }^{--}} ; \mathrm{Collal}^{r / r}$ at 4 and 6-16 weeks of age were significantly different from the wildtypes $(P<0.05)$. For females, statistical analysis was done only on measurements from 7-16 weeks of age, because there were fewer than three $\mathrm{Mmp}^{-1-} ;$ Coll al $^{r / r}$ mice for weeks 1-6. The curves were significantly influenced by genotype, $P<0.0001(\mathrm{~F}=969.29)$, and Bonferroni posttests found that $\mathrm{Mmp}^{-/-}$mice at 15 weeks of age $(P<0.05)$, Coll $^{r / r}{ }^{r / r}$ mice at 11 weeks of age $(P<0.05)$, and $\mathrm{Mmp}^{-/-} ;$Colla $^{r / r}$ mice at $7-16$ weeks of age were significantly different $(P<0.001)$ from wild-type mice. The size of the calvarial foramen, relative bone volume (BV/ TV), trabecular thickness (DT-Tb.Th), cortical thickness at the diaphysis (DT-C.Th.-Diaph), and trabecular separation (TRI-Tb.Sp.) were analyzed with two-sided Student's $t$-test.

\section{ACKNOWLEDGMENTS}

The authors thank Kerstin Dehne and Jake Lee for technical support, Dr. Stephen Krane for Colla1 ${ }^{r / r}$ mice, Dr. Shigeyoshi Itohara for Mmp2-/- mice, and Drs. Sylvain Provot and Andrew J. Ewald for helpful comments on the 
manuscript. M.E. received a fellowship from The Danish Medical Research Council, and A.E. received a fellowship from The Serono Foundation for the Advancement of Medical Science.

Grant sponsor: National Institutes of Health; Grant number: R01 AR046238; Grant number: CA094168; Grant number: CA098075; Grant sponsor: UCSF Breast Cancer SPORE P50 CA058207 and Core C of P01 CA072006; Grant sponsor: The Sandler Program in Basic Sciences; Grant sponsor: The National Technology Center for Networks and Pathways; Grant number: U54 RR020843; Grant sponsor: The Danish Medical Research Council; Grant sponsor: The Serono Foundation for the Advancement of Medical Science.

\section{REFERENCES}

Aimes RT, Quigley JP. Matrix metalloproteinase-2 is an interstitial collagenase. Inhibitor-free enzyme catalyzes the cleavage of collagen fibrils and soluble native type I collagen generating the specific 3/4and 1/4-length fragments. J Biol Chem 1995;270:5872-5876. [PubMed: 7890717]

Al Aqeel A, Al Sewairi W, Edress B, Gorlin RJ, Desnick RJ, Martignetti JA. Inherited multicentric osteolysis with arthritis: a variant resembling Torg syndrome in a Saudi family. Am J Med Genet 2000;93:11-18. [PubMed: 10861676]

Al-Mayouf SM, Majeed M, Hugosson C, Bahabri S. New form of idiopathic osteolysis: nodulosis, arthropathy and osteolysis (NAO) syndrome. Am J Med Genet 2000;93:5-10. [PubMed: 10861675]

Barsh GS, David KE, Byers PH. Type I osteogenesis imperfecta: a nonfunctional allele for pro alpha 1 (I) chains of type I procollagen. Proc Natl Acad Sci U S A 1982;79:3838-3842. [PubMed: 6954526]

Barsh GS, Roush CL, Bonadio J, Byers PH, Gelinas RE. Intron-mediated re-combination may cause a deletion in an alpha 1 type I collagen chain in a lethal form of osteogenesis imperfecta. Proc Natl Acad Sci U S A 1985;82:2870-2874. [PubMed: 3857621]

Bonadio J, Holbrook KA, Gelinas RE, Jacob J, Byers PH. Altered triple helical structure of type I procollagen in lethal perinatal osteogenesis imperfecta. J Biol Chem 1985;260:1734-1742. [PubMed: 2981871]

Cheng SL, Lai CF, Fausto A, Chellaiah M, Feng X, McHugh KP, Teitelbaum SL, Civitelli R, Hruska KA, Ross FP, Avioli LV. Regulation of alphaVbeta3 and alphaVbeta5 integrins by dexamethasone in normal human osteoblastic cells. J Cell Biochem 2000;77:265-276. [PubMed: 10723092]

Chiusaroli R, Maier A, Knight MC, Byrne M, Calvi LM, Baron R, Krane SM, Schipani E. Collagenase cleavage of type I collagen is essential for both basal and parathyroid hormone (PTH)/PTH-related peptide receptor-induced osteoclast activation and has differential effects on discrete bone compartments. Endocrinology 2003;144:4106-4116. [PubMed: 12933685]

Cowell S, Knauper V, Stewart ML, D’Ortho MP, Stanton H, Hembry RM, Lopez-Otin C, Reynolds JJ, Murphy G. Induction of matrix metalloproteinase activation cascades based on membrane-type 1 matrix metalloproteinase: associated activation of gelatinase A, gelatinase B and collagenase 3 . Biochem J 1998;331(Pt 2):453-458. [PubMed: 9531484]

Cutroneo KR. How is Type I procollagen synthesis regulated at the gene level during tissue fibrosis. J Cell Biochem 2003;90:1-5. [PubMed: 12938150]

Dacquin R, Starbuck M, Schinke T, Karsenty G. Mouse alpha1(I)-collagen promoter is the best known promoter to drive efficient Cre recombinase expression in osteoblast. Dev Dyn 2002;224:245-251. [PubMed: 12112477]

Fera E, O’Neil C, Lee W, Li S, Pickering JG. Fibroblast growth factor-2 and remodeled type I collagen control membrane protrusion in human vascular smooth muscle cells: biphasic activation of Rac1. J Biol Chem 2004;279:35573-35582. [PubMed: 15166228]

Heino J. The collagen receptor integrins have distinct ligand recognition and signaling functions. Matrix Biol 2000;19:319-323. [PubMed: 10963992]

Holmbeck K, Bianco P, Caterina J, Yamada S, Kromer M, Kuznetsov SA, Mankani M, Robey PG, Poole AR, Pidoux I, Ward JM, Birkedal-Hansen H. MT1-MMP-deficient mice develop dwarfism, osteopenia, arthritis, and connective tissue disease due to inadequate collagen turnover. Cell 1999;99:81-92. [PubMed: 10520996]

Inoue K, Mikuni-Takagaki Y, Oikawa K, Itoh T, Inada M, Noguchi T, Park JS, Onodera T, Krane SM, Noda M, Itohara S. A crucial role for MMP-2 in osteocytic canalicular formation and bone metabolism. J Biol Chem 2006;281:33814-33824. [PubMed: 16959767] 
Itoh T, Ikeda T, Gomi H, Nakao S, Suzuki T, Itohara S. Unaltered secretion of beta-amyloid precursor protein in gelatinase A (matrix metalloproteinase 2)-deficient mice. J Biol Chem 1997;272:2238922392. [PubMed: 9278386]

Jiang Y, Zhao JJ, Mitlak BH, Wang O, Genant HK, Eriksen EF. Recombinant human parathyroid hormone (1-34) [teriparatide] improves both cortical and cancellous bone structure. J Bone Miner Res 2003;18:1932-1941. [PubMed: 14606504]

Kalajzic I, Terzic J, Rumboldt Z, Mack K, Naprta A, Ledgard F, Gronowicz G, Clark SH, Rowe DW. Osteoblastic response to the defective matrix in the osteogenesis imperfecta murine (oim) mouse. Endocrinology 2002;143:1594-1601. [PubMed: 11956140]

Le Bihan D, Breton E, Lallemand D, Grenier P, Cabanis E, Laval-Jeantet M. MR imaging of intravoxel incoherent motions: application to diffusion and perfusion in neurologic disorders. Radiology 1986;161:401-407. [PubMed: 3763909]

Liu X, Wu H, Byrne M, Jeffrey J, Krane S, Jaenisch R. A targeted mutation at the known collagenase cleavage site in mouse type I collagen impairs tissue remodeling. J Cell Biol 1995;130:227-237. [PubMed: 7790374]

Mann V, Hobson EE, Li B, Stewart TL, Grant SF, Robins SP, Aspden RM, Ralston SH. A COL1A1 Sp1 binding site polymorphism predisposes to osteo-porotic fracture by affecting bone density and quality. J Clin Invest 2001;107:899-907. [PubMed: 11285309]

Martignetti JA, Aqeel AA, Sewairi WA, Boumah CE, Kambouris M, Mayouf SA, Sheth KV, Eid WA, Dowling O, Harris J, Glucksman MJ, Bahabri S, Meyer BF, Desnick RJ. Mutation of the matrix metalloproteinase 2 gene (MMP2) causes a multicentric osteolysis and arthritis syndrome. Nat Genet 2001;28:261-265. [PubMed: 11431697]

Montgomery AM, Reisfeld RA, Cheresh DA. Integrin alpha v beta 3 rescues melanoma cells from apoptosis in three-dimensional dermal collagen. Proc Natl Acad Sci U S A 1994;91:8856-8860. [PubMed: 7522323]

Nadeau JH. Modifier genes in mice and humans. Nat Rev Genet 2001;2:165-174. [PubMed: 11256068]

Oh J, Takahashi R, Adachi E, Kondo S, Kuratomi S, Noma A, Alexander DB, Motoda H, Okada A, Seiki M, Itoh T, Itohara S, Takahashi C, Noda M. Mutations in two matrix metalloproteinase genes, MMP-2 and MT1-MMP, are synthetic lethal in mice. Oncogene 2004;23:5041-5048. [PubMed: 15064723]

Ohuchi E, Imai K, Fujii Y, Sato H, Seiki M, Okada Y. Membrane type 1 matrix metalloproteinase digests interstitial collagens and other extracellular matrix macromolecules. J Biol Chem 1997;272:24462451. [PubMed: 8999957]

Partridge SC, McKinnon GC, Henry RG, Hylton NM. Menstrual cycle variation of apparent diffusion coefficients measured in the normal breast using MRI. J Magn Reson Imaging 2001;14:433-438. [PubMed: 11599068]

Petitclerc E, Stromblad S, von Schalscha TL, Mitjans F, Piulats J, Montgomery AM, Cheresh DA, Brooks PC. Integrin alpha(v)beta3 promotes M21 melanoma growth in human skin by regulating tumor cell survival. Cancer Res 1999;59:2724-2730. [PubMed: 10363998]

Ralston SH, Uitterlinden AG, Brandi ML, Balcells S, Langdahl BL, Lips P, Lorenc R, Obermayer-Pietsch B, Scollen S, Bustamante M, Husted LB, Carey AH, Diez-Perez A, Dunning AM, Falchetti A, Karczmarewicz E, Kruk M, van Leeuwen JP, van Meurs JB, Mangion J, McGuigan FE, Mellibovsky L, del Monte F, Pols HA, Reeve J, Reid DM, Renner W, Rivadeneira F, van Schoor NM, Sherlock RE, Ioannidis JP. Large-scale evidence for the effect of the COLIA1 Sp1 polymorphism on osteoporosis outcomes: the GENOMOS study. PLoS Med 2006;3:e90. [PubMed: 16475872]

Rouzier C, Vanatka R, Bannwarth S, Philip N, Coussement A, Paquis-Flucklinger V, Lambert JC. A novel homozygous MMP2 mutation in a family with Winchester syndrome. Clin Genet 2006;69:271276. [PubMed: 16542393]

Rozmahel R, Wilschanski M, Matin A, Plyte S, Oliver M, Auerbach W, Moore A, Forstner J, Durie P, Nadeau J, Bear C, Tsui LC. Modulation of disease severity in cystic fibrosis transmembrane conductance regulator deficient mice by a secondary genetic factor. Nat Genet 1996;12:280-287. [PubMed: 8589719]

Shrivastava A, Radziejewski C, Campbell E, Kovac L, McGlynn M, Ryan TE, Davis S, Goldfarb MP, Glass DJ, Lemke G, Yancopoulos GD. An orphan receptor tyrosine kinase family whose members serve as nonintegrin collagen receptors. Mol Cell 1997;1:25-34. [PubMed: 9659900] 
Stickens D, Behonick DJ, Ortega N, Heyer B, Hartenstein B, Yu Y, Fosang AJ, Schorpp-Kistner M, Angel P, Werb Z. Altered endochondral bone development in matrix metalloproteinase 13-deficient mice. Development 2004;131:5883-5895. [PubMed: 15539485]

Stringa E, Knauper V, Murphy G, Gavrilovic J. Collagen degradation and platelet-derived growth factor stimulate the migration of vascular smooth muscle cells. J Cell Sci 2000;113(Pt 11):2055-2064. [PubMed: 10806116]

Strongin AY, Collier I, Bannikov G, Marmer BL, Grant GA, Goldberg GI. Mechanism of cell surface activation of $72-\mathrm{kDa}$ type IV collagenase. Isolation of the activated form of the membrane metalloprotease. J Biol Chem 1995;270:5331-5338. [PubMed: 7890645]

Tam EM, Moore TR, Butler GS, Overall CM. Characterization of the distinct collagen binding, helicase and cleavage mechanisms of matrix metalloproteinase 2 and 14 (gelatinase A and MT1-MMP): the differential roles of the MMP hemopexin c domains and the MMP-2 fibronectin type II modules in collagen triple helicase activities. J Biol Chem 2004;279:43336-43344. [PubMed: 15292230]

Tournier JM, Polette M, Hinnrasky J, Beck J, Werb Z, Basbaum C. Expression of gelatinase A, a mediator of extracellular matrix remodeling, by tracheal gland serous cells in culture and in vivo. J Biol Chem 1994;269:25454-25464. [PubMed: 7929245]

Vu TH, Shipley JM, Bergers G, Berger JE, Helms JA, Hanahan D, Shapiro SD, Senior RM, Werb Z. MMP-9/gelatinase B is a key regulator of growth plate angiogenesis and apoptosis of hypertrophic chondrocytes. Cell 1998;93:411-422. [PubMed: 9590175]

Zankl A, Bonafe L, Calcaterra V, Di Rocco M, Superti-Furga A. Winchester syndrome caused by a homozygous mutation affecting the active site of matrix metalloproteinase 2. Clin Genet 2005;67:261-266. [PubMed: 15691365]

Zankl A, Pachman L, Poznanski A, Bonafe L, Wang F, Shusterman Y, Fishman DA, Superti-Furga A. Torg syndrome is caused by inactivating mutations in MMP2 and is allelic to NAO and Winchester syndrome. J Bone Miner Res 2007;22:329-333. [PubMed: 17059372]

Zhao W, Byrne MH, Boyce BF, Krane SM. Bone resorption induced by parathyroid hormone is strikingly diminished in collagenase-resistant mutant mice. J Clin Invest 1999;103:517-524. [PubMed: 10021460]

Zhao W, Byrne MH, Wang Y, Krane SM. Osteocyte and osteoblast apoptosis and excessive bone deposition accompany failure of collagenase cleavage of collagen. J Clin Invest 2000;106:941-949. [PubMed: 11032854]

Zhao H, Ross FP, Teitelbaum SL. Unoccupied alpha(v)beta3 integrin regulates osteoclast apoptosis by transmitting a positive death signal. Mol Endocrinol 2005;19:771-780. [PubMed: 15591537]

Zhou Z, Apte SS, Soininen R, Cao R, Baaklini GY, Rauser RW, Wang J, Cao Y, Tryggvason K. Impaired endochondral ossification and angiogenesis in mice deficient in membrane-type matrix metalloproteinase I. Proc Natl Acad Sci U S A 2000;97:4052-4057. [PubMed: 10737763]

Zielenski J, Corey M, Rozmahel R, Markiewicz D, Aznarez I, Casals T, Larriba S, Mercier B, Cutting GR, Krebsova A, Macek M Jr, Langfelder-Schwind E, Marshall BC, DeCelie-Germana J, Claustres M, Palacio A, Bal J, Nowakowska A, Ferec C, Estivill X, Durie P, Tsui LC. Detection of a cystic fibrosis modifier locus for meconium ileus on human chromosome 19q13. Nat Genet 1999;22:128129. [PubMed: 10369249] 

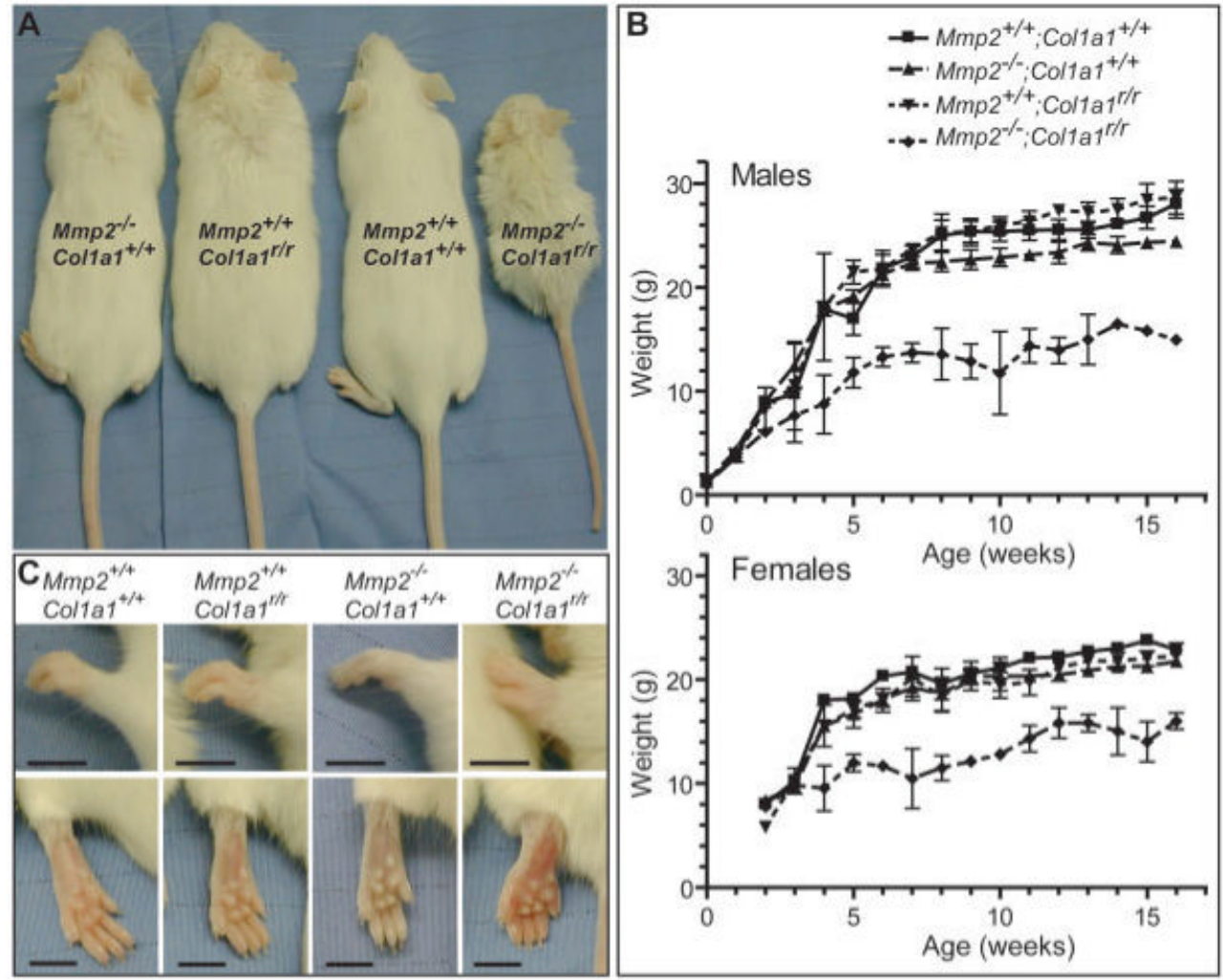

Fig. 1.

$\mathrm{Mmp}^{-/-} ;$Collal $^{r / r}$ mice are severely growth retarded, with swollen and hyperextended metacarpophalangeal joints. A: Adult (age, 8-11 weeks) wild-type $\left(\mathrm{Mmp2}^{+/+} ; \mathrm{Collal}^{+/+}\right)$, $\mathrm{Mmp2}^{-/-} ;$Collal $^{+/+}, \mathrm{Mmp2}^{+/+} ;$Collal $^{r / r}$, and $\mathrm{Mmp2}^{-/-} ;$Collal $^{r / r}$ mice (backcrossed to FVB/ n). B: Growth curves of male (top) and female (bottom) $\mathrm{Mmp2}^{+/+} ; \mathrm{Collal}^{+/+}$, $\mathrm{Mmp2}^{-/-} ; \mathrm{Collal}^{+/+}, \mathrm{Mmp2}^{+/+} ; \mathrm{Collal}^{r / r}$, and $\mathrm{Mmp2}^{-/-} ;$Collal $^{r / r}$ mice weighed weekly (mean $\pm \mathrm{SD}$ from repeated measurements), $\mathrm{n}=3$ for $\mathrm{Mmp}^{+/+} ; \mathrm{Collal}^{+/+}, \mathrm{Mmp}^{-/-} ; \mathrm{Collal}^{+/+}$, and $\mathrm{Mmp2}^{+/+} ;$Colla1 $^{r / r}$. However, because some $\mathrm{Mmp2}^{-/-} ;$Collal $^{r / r}$ mice died, six

$\mathrm{Mmp}^{-/-} ; \mathrm{Collal}^{\mathrm{r} / \mathrm{r}}$ mice were followed up for each sex, although not all mice could be weighed at all time points. The curves are significantly different for both males and females using twoway analysis of variance repeated-measurements test. C: Photographs of front (top) and hind (bottom) paws from 7-week-old $\mathrm{Mmp2}^{+/+} ; \mathrm{Collal}^{+/+}, \mathrm{Mmp2}^{-/-} ; \mathrm{Collal}^{+/+}$, $\mathrm{Mmp2}^{+/+} ;$Collal $^{r / r}$, and $\mathrm{Mmp2}^{-/-} ;$Collal $^{r / r}$ mice. Scale bar is $5 \mathrm{~mm}$. 

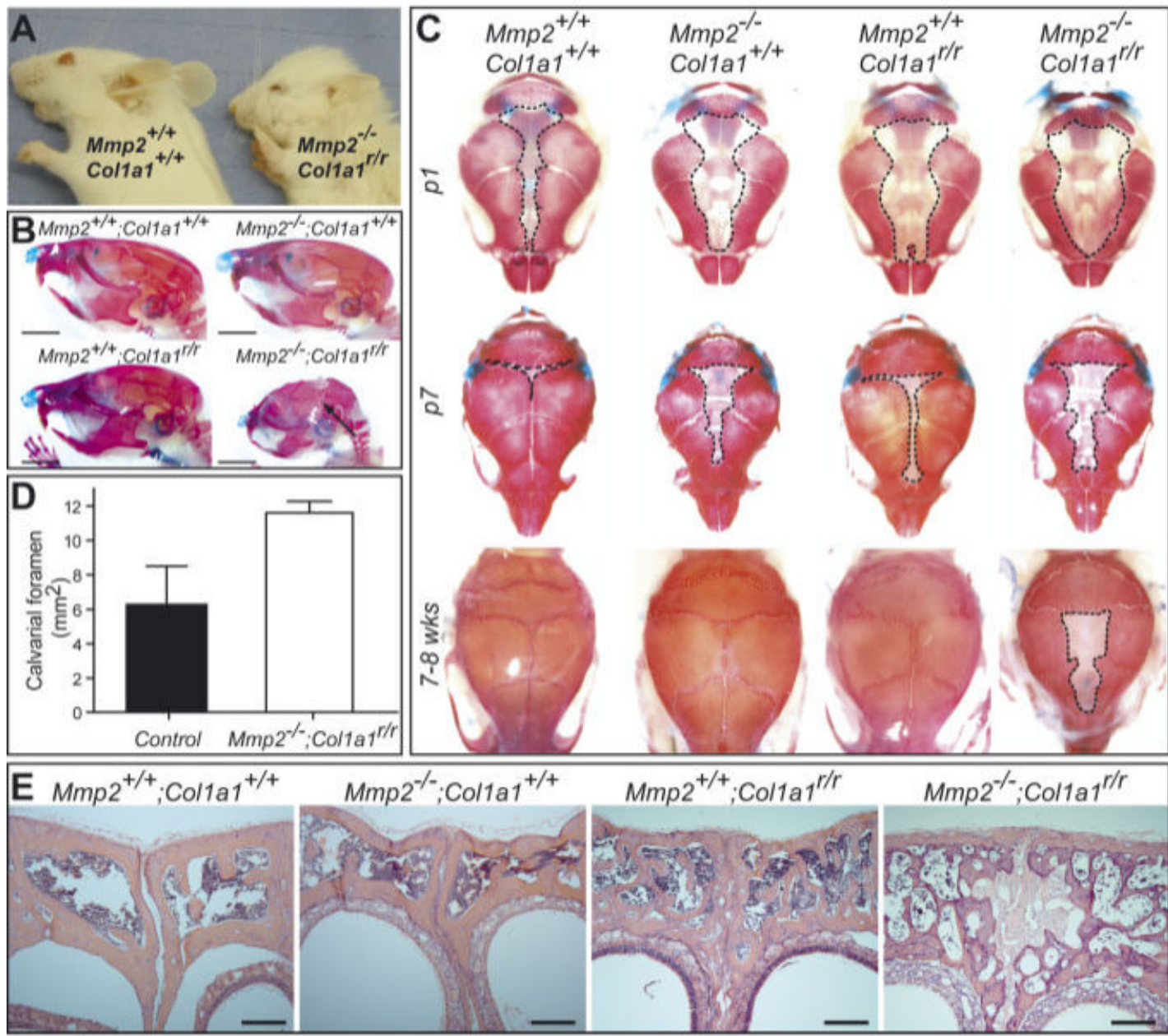

Fig. 2.

Mmp $^{-/-} ;$Colla1 $^{r / r}$ mice have abnormal calvarial bone development. A: Side view of heads of 7-week-old $\mathrm{Mmp2}^{+/+} ; \mathrm{Collal}^{+/+}$and $\mathrm{Mmp2}^{-/-} ; \mathrm{Collal}^{\mathrm{r/r}}$ mice. B: Side view of skulls of 8week-old $\mathrm{Mmp2}^{+/+} ; \mathrm{CollaI}^{+/+}, \mathrm{Mmp2}^{-/-} ; \mathrm{CollaI}^{+/+}, \mathrm{Mmp2}^{+/+} ; \mathrm{Collal}^{\mathrm{r} / \mathrm{r}}$, and $\mathrm{Mmp2}^{-\mathrm{I}^{-}}$; Collal ${ }^{r / r}$ mice stained with Alcian blue (cartilage) and alizarin red (bone). Arrow points to open calvarial sutures in adult $\mathrm{Mmp2}^{-/-} ; \mathrm{Collal}^{\mathrm{r} / \mathrm{r}}$ mice. Scale bar is $5 \mathrm{~mm}$. C: Top-view of skulls from the different genotypes after staining with Alcian blue and Alizarin red at birth (p1), 7 days of age (p7), and 7-8 weeks of age (7-8 wks). D: Quantification of the calvarial foramen (outlined with dashed lines in $\mathrm{C}$ ) at birth (mean $\pm \mathrm{SD}$ ). The calvarial foramen was significantly larger $(P=0.006$, two-sided Student's $t$-test $)$ in $\mathrm{Mmp}^{-{ }^{--}} ;$Collal $^{r / r}$ animals $(\mathrm{n}=$ 4) than in control littermates with at least one wildtype Mmp2 and Collal allele $(\mathrm{n}=3)$. E: Histology of the frontal bones from 8-week-old mice stained with hematoxylin and eosin. Scale bar $=200 \mu \mathrm{m}$. 

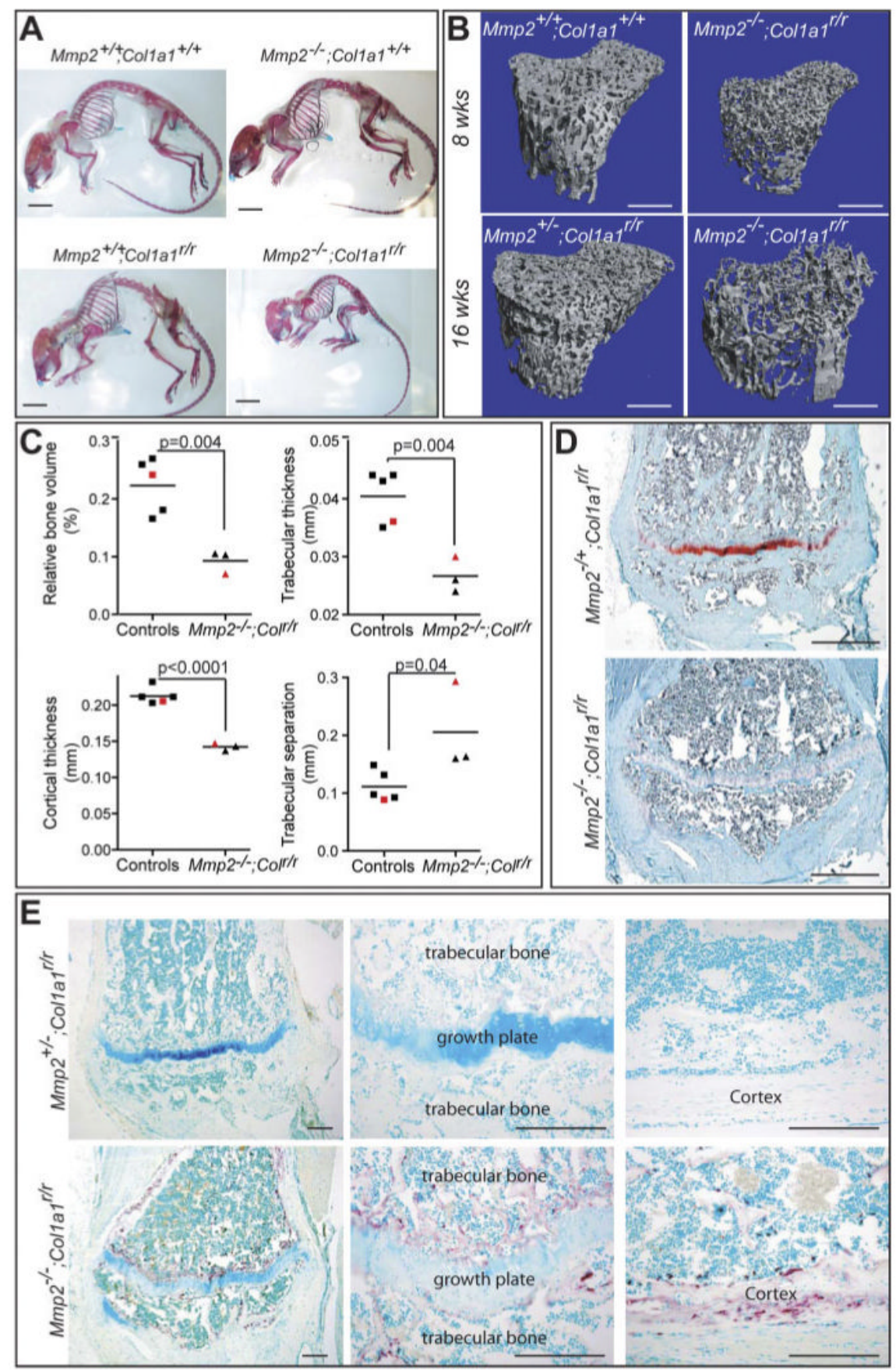

Fig. 3.

Osteopenia in long bones of $\mathrm{Mmp}^{-/-} ;$Colla $^{r / r}$ mice. A: Whole skeletons of 8-week-old animals, stained with Alcian blue (cartilage) and Alizarin red (bone). B: Microcomputed tomography (micro-CT) of tibiae of $\mathrm{Mmp}^{-/-} ; \mathrm{Collal}^{r / r}$ and controls at 8 and 16 weeks of age. C: Relative bone volume (BV/TV), trabecular thickness (DT-Tb.Th), cortical thickness at the diaphysis (DT-C.Th.-Diaph), and trabecular separation (TRI-Tb.Sp.) were determined by micro-CT of tibiae from $\mathrm{Mmp}^{-/-} ; \mathrm{Collal}^{r / r}$ and their aged-matched controls (two $\mathrm{Mmp2}^{+/+} ; \mathrm{Collal}^{+/+}$, one $\mathrm{Mmp2}^{--_{-}} ; \mathrm{Collal}^{+/+}$, one $\mathrm{Mmp2}^{+/+} ; \mathrm{Collal}^{r / r}$, and one $\mathrm{Mmp}^{+/-} ;$Collal $\left.^{r / r}\right)$. All mice were 7-8 weeks old, except the two mice represented with red symbols that were 16 weeks old. All measurements were significantly different by two-sided 
Student's $t$-test. D: Safranin-O staining of tibia from 16-week-old Mmp $2^{-/-} ;$Collal $^{r / r}$ and $\mathrm{Mmp}^{-/+} ;$Coll $^{1 / r / r}$ littermates showing reduced trabecular bone in the former. E: Increased tartrate-resistant acid phosphatase (TRAP)-positive (purple) osteoclasts in both trabecular bone and cortex of tibiae from $\mathrm{Mmp}^{-{ }^{--}} ;$Coll al $^{r / r}$ counter-stained with fast green. Scale bar $=1 \mathrm{~cm}$ in $\mathrm{A}, 5 \mathrm{~mm}$ in $\mathrm{B}, 500 \mu \mathrm{m}$ in $\mathrm{D}, 200 \mu \mathrm{m}$ in $\mathrm{E}$. 


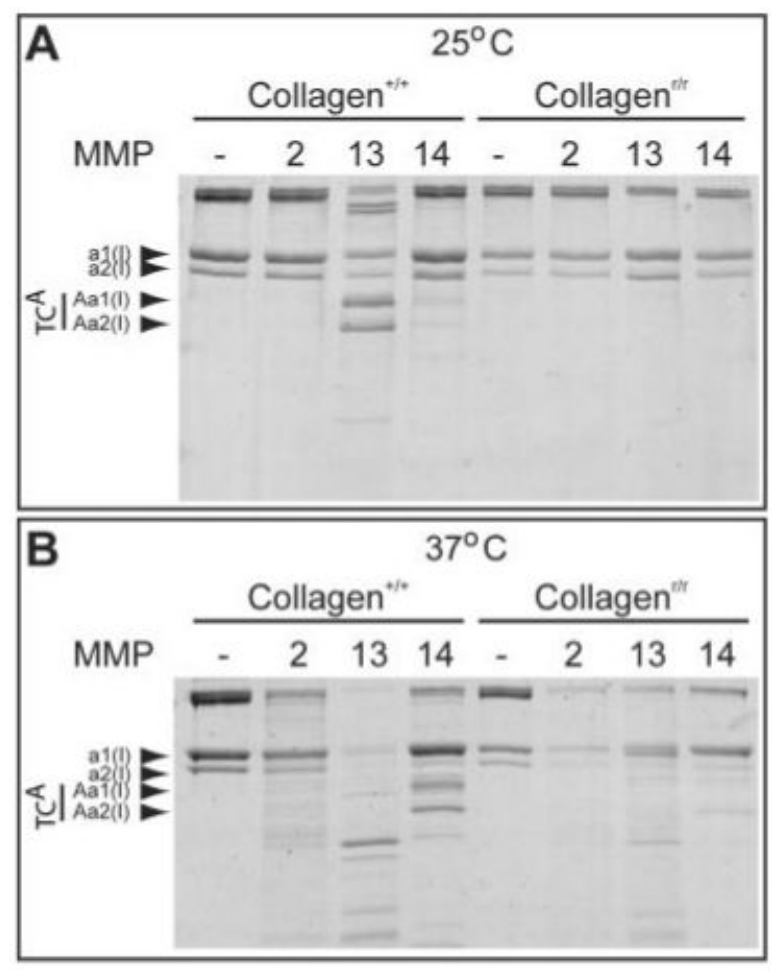

Fig. 4.

Collagenase-resistant type I collagen ${ }^{\mathrm{r} / \mathrm{r}}$ is degraded by matrix metalloproteinase 2 (MMP2) at physiological temperature. A,B: Wild-type $\left(\right.$ collagen $^{+/+}$) and mutant $\left(\right.$collagen $\left.^{\mathrm{r} / \mathrm{r}}\right)$ type I collagen was digested in vitro for $1 \mathrm{hr}$ with MMP2, -13 , or -14 at $25^{\circ} \mathrm{C}(\mathrm{A})$ and $37^{\circ} \mathrm{C}(\mathrm{B})$. Col1a1 (a1(I)) and Col1 $22(\mathrm{a} 2(\mathrm{I}))$ chains and their $\mathrm{TC}^{\mathrm{A}}$ cleavage products (Aa1(I) and Aa2 (I)) are indicated. At $37^{\circ} \mathrm{C}$, the mutant Col1 $\alpha 1$ chain is not cleaved to the normal fragments, but is degraded by MMPs, especially by MMP2. Trace amounts of cleaved TC $^{\mathrm{A}}$ (Aa2(I)) from the nonmutant Col1 $\alpha 2$ chain were found when digesting mutant type I collagen ${ }^{\mathrm{r} / \mathrm{r}}$. 


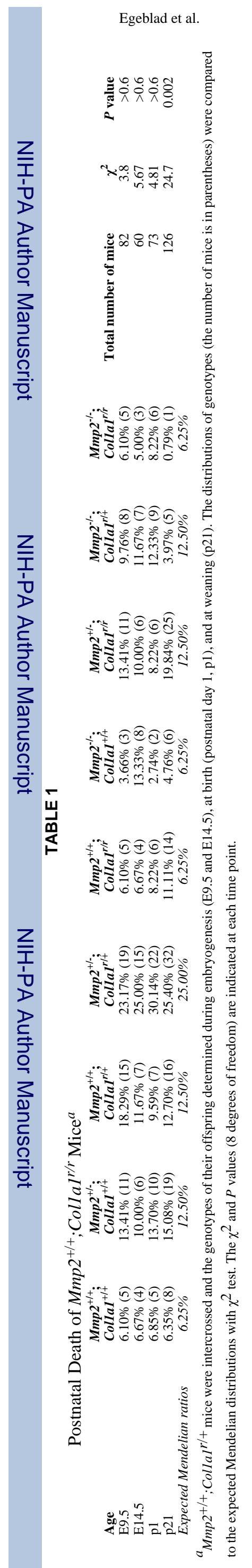




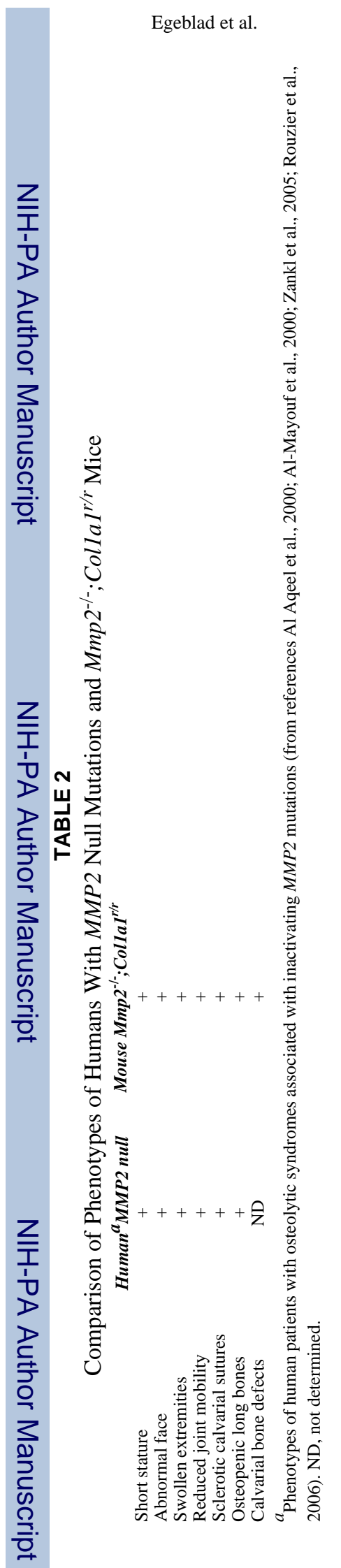

Page 19

Dev Dyn. Author manuscript; available in PMC 2008 November 7. 